\title{
Influential Factors Of Executives' Equity-Based Revenue In Chinese-Listed Companies
}

Lei Li, Tongji University, China

Pierre-Yves Sanséau, Grenoble Ecole de Management, France

\begin{abstract}
In the Chinese context of economic reform and restructuring to establish the modern corporate system, new models of executives' equity-based revenue are tested. Stock option income is currently becoming a critical part in the whole package offering to the executives. In this research, we examine the influential factors of executives' equity-based revenue in 127 Chineselisted companies. It appears that business performance is positively related to executives' equitybased compensation, that there is no significant correlation between executives' equity-based compensation and corporate size, that industry is an influential factor of executives' equity-based compensation, and that there is no significant correlation between executives' equity-based compensation and tenure. Based on these findings, we suggest future improvements to establish a healthier equity incentive system in China.
\end{abstract}

Keywords: CEO; Compensation Policies; Stock Options; China

\section{INTRODUCTION}

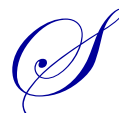

tock option income has currently accounted for a critical part in the whole package offered to executives. Its development, to some extent, fully proved the necessity of long-term incentives to managers, in particular to the chief executive officers (CEO) since stock price reflects the long-term investment value of the firm in the efficient capital market (Chidambaran and Nagpurnanand, 2003; Johnson and Tian, 2000; Peterson et al., 2002; Ross, 2004). If the manager's attention is directed to short-term profit, then the means of strengthening the competency of the company, such as research and development, training employees, market expanding, and his own income, will apparently be limited to the short-term compensation as salary and bonus. The lack of foresight reflecting those practises could be avoided by long-term incentive instruments, which would link the company's development with the executive's personal growth in terms of both career and financial security (Cadenillas et al., 2004; Carpenter, 2000; Liu et al., 2011; Sircar and Xiong, 2007).

Currently in China, this is a crucial time for economic reform and restructuring to establish a modern corporate system adapted to the Chinese reality. In particular, the development of compensation system for publiclisted companies is a key priority for corporate governance. This issue demands consideration of both Western theory and practice and the Chinese perspective. In 1997, Shanghai Jinling and Yidian Holding, two listed companies affiliated with Shanghai Electronics Holding Group, began to adopt the stock option plan, which made them pioneers of Chinese stock option revolution. From then on, companies in the cities of Shanghai, Beijing, Wuhan, Shenzhen, and Shenyang carried out their own compensation proposals with experimental stock options, resulting in beneficial effects and the accumulation of a great deal of practical experience.

This paper describes an empirical test of practices of equity-based compensation for executives in Chinese publicly-listed companies and answers the following questions in order to find the internal economic rules and existing problems in the current practice: 
1. What determines the executives' equity-based compensation?

2. Do Chinese stock market practices support the theoretically deduced determinants?

3. Are there additional factors not yet unidentified?

The structure of the paper is organized in four parts. The first part aims to review the relevant literature in order to define the hypotheses of the research. The second part presents the research method, the data source and the variables. The third part provides the results of the research and the fourth part is a discussion based on the issues and implications of the research. In the conclusion, we offer several suggested improvements consistent with the Chinese context.

\section{LITERATURE REVIEW - DETERMINANTS OF EXECUTIVE'S STOCK OPTIONS}

North American and European researchers have carried out a great deal of empirical research on the determinants of executives' equity compensation, such as CEO performance, governance structure, CEO's personal characteristics, and firm size. Similar research in China has emerged only in recent years by figuring out a reasonable compensation system for top management, which became a sensitive topic out of interest to all levels of society (Li and Caiping, 2007; Wei, 2000; Yang \& Ma, 2005; Zhou, 2003).

\section{Performance-compensation Sensitivity}

Principal-agency theory indicates that an important aspect of agent incentive is to agree on compensation (Jensen and Meckling, 1976). Researchers have already established the optimal compensation contract on the basis of this theoretical angle. Agency theory predicts that CEOs should be motivated to act in their shareholders' interest by incentive contracts, with compensation related to business performance. Thus, compensation packages are heavily dependent on the firm's stock price, which is viewed as a summary statistic of the CEO's performance. Although this concept is theoretically precise and reasonable, it is rather difficult or even impossible to manipulate in practice because it is based on the assumption that the following two conditions occur simultaneously. One condition is that the enterprise is thoroughly and totally under the control of the CEO. If this is not met, managers will receive profit from other means, such as collectivity consumption. The other condition is that managers are forbidden to resign and leave the company. If they could, they are then entitled to bargain with prospective employers or simply choose to leave if they could not agree with the owners. Based on the assumption that the principals could only reward or punish the agents by the observed outcome index (performance), Western scholars have emphasized empirical examination on performance-compensation sensitivity and tried to demonstrate that there is a close relationship between these two factors. Consequently, we should have sufficient evidence to reward managers according to their contributions (Laffont and Martimort, 2002; McConvill, 2005).

However, the empirical results turned out differently. The most important reason lies in the variety of study methods, including different ways of collecting data, analysing statistics, selecting samples and periods, as well as the existence of adjustment variables and co-linearity (Gomez-Mejia, 1994). In the end, most of these studies reached the conclusion that the assumption of correlation between performance and executive compensation was not significant (Hall and Liebman, 1998; Jensen and Murphy, 1990; Mcknight et al., 1996).

\section{Governance Structure and Executive Compensation}

The design of executive compensation is regarded not only as an instrument for solving the agency problem between managers and shareholders, but also as part of the agency problem itself. Boards of publicly traded companies with dispersed ownership cannot be expected to bargain at arm's length with managers. Managers wield substantial influence over their own pay. As long as the shareholders could effectively influence managers' compensation, or if there were watchdogs who could monitor managers' decision-making procedures, perhaps excessive compensation could be avoided and managers' total compensation would not deviate too far from indexes of enterprise performance. However, pay will be higher and/or less sensitive to performance in firms in which managers have relatively more power. Other conditions being equal, managers would tend to have more power when: (1) the board is relatively weak or ineffective, (2) there are no large outside shareholders, (3) there are fewer 
institutional shareholders, or (4) managers are protected by anti-takeover arrangements (Core and Guay, 1999; Cragg and Dyck, 2000; Cyert et al., 2002).

Other empirical studies testing the conclusion of managerial power theory focus on the sensitivity analysis concerning the decision function of the corporate governance structure on the compensation issue. Because the corporate governance structure determines the degree of supervision on managers, the relationship between performance and compensation is adjusted by corporate monitoring technology. Theoretically, large shareholders have the ability to punish and reward the managers; therefore, there must be some relationship between executive's compensation and the proportion of large shareholders in the board (Benz et al., 2001; Bertrand and Mullainathan, 2001; Cycert et al., 2002).

\section{CEO's Personal Characteristics-compensation Correlation}

Ciscel and Carroll (1980) view CEO human capital as another crucial determinant of CEO compensation. Age, tenure and educational experience are the representative variables of human capital in their studies. For instance, Murphy (1986) found that the longer the tenure, the more knowledge the owner or board would have and the less necessary would be the link between the enterprise's performance and the manager's compensation. Hill and Phan (1991) believed that the longer the managers' tenure, the more stable then is his position and the more ability they would have in weakening the relationship between performance and compensation. Hartzell (1998) separated the incentive tenure into a position-ceasing incentive, career incentive and performance incentive, corresponding to the executive about to be retire, tenure foreseer and the executive with infinite tenure. When executives calculate the probability of being terminated, their performance-compensation sensitivity, as well as manager's momentum of getting high compensation through sound performance, is less. Thus, the incentive system performance link becomes less efficient or inefficient.

\section{Firm Size and Executive Compensation}

Empirical studies commonly support a strong correlation between size and executive compensation. Demsetz and Lehn (1985) deemed that since corporate essence and product market were settled, there existed an optimal corporate size and executive equity granting level. If the former was larger, the latter would be higher. Smith and Watts (1992) argued that larger companies demanded managers with more talent. Therefore, managers in larger companies should have higher equity-based compensation. Under the classical assumption about the manager function related with risk-taking and corporate size, the empirical result found by Himmelber et al. (1999) was that the equity incentive level would be decreased as the corporate size became larger. Core and Guay (1999) used the logarithm of stock price to operationalize corporate size, which confirmed Himmelber et al. findings (1999). Under different capital structures, the best compensation for executives is different. In enterprises with a high liability ratio, compensation-performance sensitivity of executives is particularly low. Industrial structure and pressure of restriction are decisive predictable variables of executive's compensation. In restricted industry, managers' income is usually lower than their counterparts.

\section{Equity Incentive in China}

Chinese scholars started to carry out the empirical studies on determinants of executive compensation in the beginning of the $21^{\text {st }}$ century. Through statistical analysis and empirical work, they have reached many conclusions based on Chinese contemporary situations and raised a great amount of recommendations. It has been proven by econometric results that there are certain kinds of correlation between executive's compensations and the corporate performance, governance character, managers' feature and corporate size (Zhang and Tao, 2002; Zhou and Sun, 2003).

To sum up, Chinese studies agree on the following conclusions: (1) there was no or a small correlation between an executive's compensation and performance; (2) there was a significant positive correlation between executive compensation and enterprise size; (3) executive shareholding was not related with enterprise performance, and the effect of the equity incentive was not obvious and (4) there was a positive correlation between an 
executive's compensation and his tenure (Li and Wang, 2007; Peng, 2006; Xie, 2004; Yu and Peng , 2001; Zhang, 2003; Zhou, 2003).

\section{RESEARCH HYPOTHESES}

This paper focuses on the study of the influential factors of stock option compensation for executives in China, mainly using multiple liner regression method and based on the theory of model impact assessment. Based on the literature review, enterprise performance, size, corporate industry, managers' human capital, and the corporation's governance structure mostly affect executives' total remuneration. The current stock option system in China is only beginning, unlike the established practice in Western countries. However, this kind of system has existed in China's stock market in terms of performance stock, virtual options and some other alternative stock sorts. Our research tests five hypothesizes to study the relationships between executives' stock option revenue and companies' performance, corporate size, managers' human capital and corporate governance structure of Chineselisted companies. We establish models and use real data in financial reports of Chinese-listed companies to carry out our empirical tests.

Hypothesis 1: There is significant positive correlation between executives' stock option income and corporate operation performance.

Hypothesis 2: The size of the company is positively related with executives' stock option income.

Hypothesis 3: The nature of the industry that the company is in will have impact on executives' stock option income.

Hypothesis 4: Executives' tenure will have impact on executives' stock option revenue.

Hypothesis 5: For the fifth hypothesis, two sub-hypotheses are offered: 1) Hypothesis 5(A) - the higher the proportion of independent directors of the board, the lower the stock option compensation will be and 2) Hypothesis 5(B) - the higher the proportion of institutional shareholders, the lower the stock option compensation will be.

\section{METHOD}

\section{Data Source}

In order to test the above hypotheses, we employed archival data from the 2006 financial reports of 127 companies issued from the Chinese Shanghai stock market. Until 2008, there are totally about 840 listed companies whose shares are being traded in this stock market. The selection criteria used to create the sample is companies where executives were granted stock option compensation, such as stock options, phantom stock or appreciation stock right as our study sample. We excluded firms that carried out such equity-based incentive plans as increased share holdings because of management acquisition, employee shared ownership plans, equity incentive plan focusing on subsidiary companies. We also excluded companies where the CEO possessed the equity as a result of being granted original shares due as a founder-member of the company.

Secondly, given the adverse effect on statistical results caused by extreme value, we excluded the corporations with poor operation performance. Also, we excluded the companies that were given a reserved audit opinion, refusal audit opinion and negative audit opinion. We only selected companies with yearly revenue of more than 400 million Yuan in order to make sure the company had the capacity to prove the possibility of establishing a healthy and modern enterprise system.

Thirdly, in the sample, we excluded companies in which the president also assumes the position of CEO, or in which CEO is actually the company controller. We tried to select those companies in which there exist checks and balances on the CEO. 
Selecting 127 listed companies as our study sample in accordance with the above principles, we almost cover all the Chinese-listed companies in Shanghai stock market which have carried out equity-based incentives.

\section{Variable Definitions}

\section{Equity-based Incentive Compensation}

Given the nascence of Chinese-equity incentive system practices, we selected two factors common to most Chinese-listed companies: holding shares and stock price. Like Himmelberg et al. (1999), we define executives' stock option compensation as $1 \%$ of the product of executives' current year's share volume and the closing price on the final trade day of the year.

The equation is : Equity-based Compensation $(\mathrm{EBC})=$ Executives' Shareholding Volume X Stock Price $\mathrm{X} 1 \%$.

According to the data sample, the variable EBC is specified as $1 \%$ of the product of executives' share holding volume on Dec. 31, 2006 and the stock closing price for the year 2006.

\section{Performance of Listed Company}

Performance is operationalized here as Return on Equity (ROE). As a financial index, ROE not only considers time factors, but also ignores the influence of size.

Enterprise Size

Following Wei (2000) and Zhang (2003), we employ Total Capital as the representative index of Size.

\section{Executive's Tenure}

Executive tenure, in this study, refers to the total tenure of executives that will be traced from the 2005 financial report.

\section{Enterprise Industry}

We employed a dummy variable called IND as the shortened form of industry. We divided listed companies into 18 different industries: Agriculture, Building, Comprehensive Industry, Daily Consumables, Dealer and Agent, Financial Industry, Information Technology, Logistic, Manufacture Industry, Pharmaceuticals Industry, Power Industry, Raw Materials, Real Estate, Retail, Telecom, Textile, Transportation and the Travel Industry. We first calculated the average Equity-based Compensation (EBC) for each industry and ranked them in descending order. Then we gave every industry a value between 18 and 1; this value represents the industry influential power according to this descending order, as seen in Table 1.

\section{Independent Director Proportion}

The proportion of independent directors is defined as a percentage of the number of total board of directors.

\section{Institutional Shareholder Proportion}

Institutional shareholder proportion (ISP) was chosen to determine whether executive stock option compensation is affected when institutions buy liquid shares, which changes the equity structure and corporate governance. Therefore, ISP, in this study, refers to the A share proportion held by institutions, which includes exchanges, funds, companies' credit, and finance, in the top 10 shareholder list exposed in the financial reports. 
Table 1: IND Variable (Institutional Shareholder Proportion)

\begin{tabular}{|c|c|c|c|c|c|c|c|c|c|c|c|c|c|c|c|c|c|c|}
\hline Industry & 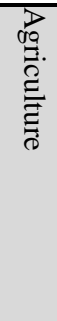 & 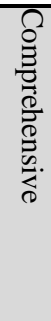 & 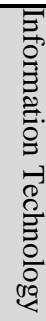 & $\begin{array}{l}\overrightarrow{8} \\
8 \\
0 \\
0 \\
0 \\
0 \\
0 \\
0 \\
0 \\
0\end{array}$ & 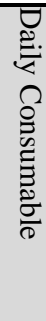 & 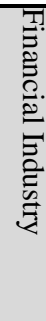 & 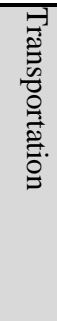 & 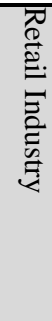 & 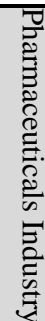 & 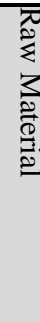 & 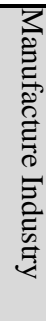 & 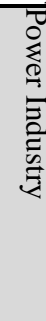 & $\begin{array}{l}5 \\
0 \\
0 \\
5 \\
\tilde{5}\end{array}$ & 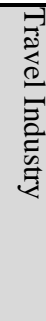 & 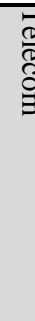 & & & $\begin{array}{l}\overrightarrow{0} \\
\stackrel{0}{0} \\
\mathbb{N} \\
\stackrel{0}{\overrightarrow{0}}\end{array}$ \\
\hline IND & 18 & 17 & 16 & 15 & 14 & 13 & 12 & 11 & 10 & 9 & 8 & 7 & 6 & 5 & 4 & 3 & 2 & 1 \\
\hline
\end{tabular}

\section{RESEARCH METHODOLOGY}

In this research, we used prior main research methods used by Gang (2000), yet we expanded the number of independent variables to get a wider test range and higher probability to find the most determinative factors. Therefore, we established a multiple-linear regression model to test the hypotheses.

In the model, stock option compensation (EBC) is the dependent variable. Performance (ROE), size (SIZE), human capital (TENURE), Industry (IND), proportion of independent directors (IDP) and proportion of institutional shareholders (ISP) are independent variables.

The model is:

$$
E B C=\alpha+\delta_{1} R O E+\delta_{2} S I Z E+\delta_{3} T E N U R E+\delta_{4} I D P+\delta_{5} I S P+\delta_{6} I N D+\varepsilon
$$

We used the method least-square of multiple-liner regression as solution and SPSS statistical software to deal with our data.

\section{RESULTS AND ANALYSIS}

\section{Analysis}

Multiple regression analysis was employed with a sample of relevant economic data from 127 listed companies in the Shanghai Stock Exchange market. By testing the relation between the dependent variable Equitybased Compensation (EBC) and the independent variables ROE (representing business performance), Total Capital (representing enterprise size), Executive's tenure (representing executives' human capital), IND (measuring the influential degree on EBC in 18 different industries), Independent Director Proportion, and Institutional Shareholder Proportion, we have validated some of our hypotheses.

Analysis of the statistic results is as follows:

The business performance variable - ROE - is positively related to executives' equity-based compensation as indicated in Table 2. This result supports the classical economic theory, thus confirms Hypothesis 1.

The research result did not support Hypothesis 2. There is no significant correlation between executives' equity-based compensation and corporate size (see Table 2). When Total Capital did not correlate, we also tried an alternative variable, such as main revenue. One possible explanation is that the relative index is more important than the absolute volume. Secondly, previous studies mainly focused on executives' whole yearly compensation. Therefore, the results they obtained showed that corporate size had a positive influence on CEO compensation, while the research only takes equity-based compensation as a dependent variable. This is the main distinctive part. 
Observing the result of the relationship between equity-based compensation and industry (see Table 2), we find that when we took industry as a dummy variable and gave each industry a value to represent its influential power according to a certain classification and order, the differences among industries appeared and the differences variation is in accordance with the variation of equity-based compensation. Thus, Hypothesis 3 has been supported. Industry, indeed, is an influential factor of executive equity-based compensation.

There is no significant correlation between executives' equity-based compensation and tenure (see Table 2). The tenure variable in this study is a representative variable of Human Capital. Tenure is more readily collected from public information. The statistical result demonstrated that tenure does not adequately represent the variable Human Capital. Hypothesis 4 needs to be tested using a different measure.

Correlation between executives' equity-based compensation and independent director proportion, as well as correlation between executives' equity-based compensation and institutional shareholding proportion, have not passed the statistic test (see Table 2). We also found no significant evidence in the test of the relation between institutional shares proportion and senior management compensation.

Table 2: Correlations

\begin{tabular}{|c|c|c|c|c|c|c|c|c|}
\hline & & EBC & ROE $(\%)$ & Size & Tenure & IDP & ISP & IND \\
\hline \multirow{7}{*}{$\begin{array}{l}\text { Pearson } \\
\text { Correlation }\end{array}$} & EBC & 1.000 & .226 & .029 & .072 & .092 & .046 & .397 \\
\hline & ROE $(\%)$ & .226 & 1.000 & -.003 & -.012 & -.054 & .244 & -.038 \\
\hline & Size & .029 & -.003 & 1.000 & .119 & .010 & .101 & -.080 \\
\hline & Tenure & .072 & -.012 & .119 & 1.000 & .030 & -.006 & .025 \\
\hline & IDP & .092 & -.054 & .010 & .030 & 1.000 & -.123 & .053 \\
\hline & ISP & .046 & .244 & .101 & -.006 & -.123 & 1.000 & -.048 \\
\hline & IND & .397 & -.038 & -.080 & .025 & .053 & $\begin{array}{l}-.048 \\
\end{array}$ & 1.000 \\
\hline \multirow[t]{7}{*}{ Sig. (1-tailed) } & EBC &. & .005 & .375 & .210 & .152 & .304 & .000 \\
\hline & ROE $(\%)$ & .005 & & .486 & .449 & .273 & .003 & .336 \\
\hline & Size & .375 & .486 & & .092 & .456 & .130 & .188 \\
\hline & Tenure & .210 & .449 & .092 &. & .369 & .473 & .389 \\
\hline & IDP & .152 & .273 & .456 & .369 &. & .085 & .279 \\
\hline & ISP & .304 & .003 & .130 & .473 & .085 & & .295 \\
\hline & IND & .000 & .336 & .188 & .389 & .279 & .295 & . \\
\hline \multirow[t]{7}{*}{$\mathbf{N}$} & EBC & 126 & 126 & 126 & 126 & 126 & 126 & 126 \\
\hline & ROE(\%) & 126 & 126 & 126 & 126 & 126 & 126 & 126 \\
\hline & Size & 126 & 126 & 126 & 126 & 126 & 126 & 126 \\
\hline & Tenure & 126 & 126 & 126 & 126 & 126 & 126 & 126 \\
\hline & IDP & 126 & 126 & 126 & 126 & 126 & 126 & 126 \\
\hline & ISP & 126 & 126 & 126 & 126 & 126 & 126 & 126 \\
\hline & IND & 126 & 126 & 126 & 126 & 126 & 126 & 126 \\
\hline
\end{tabular}

Finally, as shown in Table 3 and 4, there exists a multiple liner regression correlation between the dependent variable EBC and the independent variables ROE and IND. The regression results exhibit a substantial explanatory power. We employed stepwise method in the multiple regressions to select variables. Variable Size Tenure, IDP and ISP have been excluded from the final regression formula during the procedure of statistical analysis for not passing the $\mathrm{F}$ test. The only variables entering into the model are variables IND presenting industry differences and ROE presenting corporate performance.

Table 3: Variables Entered/Removed

\begin{tabular}{|c|c|c|c|}
\hline Model & Variables Entered & Variables Removed & Method \\
\hline 1 & IND & $\cdot$ & $\begin{array}{c}\text { Stepwise (Criteria: Probability-of-F-to-enter }<=.050, \\
\text { Probability-of-F-to-remove }>=.100) .\end{array}$ \\
\hline 2 & $\operatorname{ROE}(\%)$ & $\cdot$ & $\begin{array}{c}\text { Stepwise (Criteria: Probability-of-F-to-enter }<=.050, \\
\text { Probability-of-F-to-remove }>=.100) .\end{array}$ \\
\hline
\end{tabular}

a Dependent Variable: EBC 
Table 4: ANOVA

\begin{tabular}{|c|l|c|c|c|c|c|}
\hline Model & & Sum of Squares & df & Mean Square & F & Sig. \\
\hline 1 & Regression & 402702507.927 & 1 & 402702507.927 & 23.159 & $.000(\mathrm{a})$ \\
\hline & Residual & 2156213679.794 & 124 & 17388819.998 & & \\
\hline & Total & 2558916187.721 & 125 & & & \\
\hline 2 & Regression & 552140978.749 & 2 & 276070489.374 & 16.921 & $.000(\mathrm{~b})$ \\
\hline & Residual & 2006775208.973 & 123 & 16315245.601 & & \\
\hline & Total & 2558916187.721 & 125 & & & \\
\hline
\end{tabular}

\section{DISCUSSION OF RESULTS AND IMPLICATIONS}

\section{Results}

The analysis of data yields a deeper understanding of executive equity-based earnings, both globally and in the specific market of China.

Agency theory is taken for granted as the fundamental theory in explaining the compensation arrangement of operating managers in companies where ownership and operation rights are separated. During the period from the end of the 1960s to the end of the 1990s, this theory could not be tested through empirical tests with Western data. In most of the studies, an executive's total compensation was treated as the dependent variable. McKnight et al. (1996) first separated executive salary from bonuses, finding a significant positive relation between the bonus and corporate performance. Griner (1995) pointed out that it was wrong to mingle different kinds of compensation because long-term and short-term compensation are different; therefore, their influence factors may not be the same. Stock options are improved incentive instruments utilized in latter times. Theoretically, they will have more links with corporate performance than bonuses as they are designed to stimulate top managers to combine their own interests with those of shareholders. Thus, it seems normal to get statistical results supporting agency theory from an effective capital market.

Size, as Conyon and Leech (1994), Garen (1994), Gregg et al. (1993) concluded, has a positive relation with executives' total package, but it will not be a good explanatory factor for long-term incentive compensation. Both of these two relationships were testified with the Chinese data market. We consider this as a fairly good result that demonstrates a positive development being processed in the Chinese financial environment. In 2006, a reform verifying stock liquidity took place in China. This share merger reform released abundant shares from trading limitations and is viewed as a milestone in discovering the investment value of the Chinese stock market. As stock prices gradually return to their investment value, equity-based compensation will extend greater incentive power in the near future.

The hypothesis that the degree of corporate governance will impact executives' equity compensation is an extension proposition of agency theory. Most empirical studies have shown that agency theory explains a part of the executives' compensation. Therefore, corporate governance structure must serve as part of the influence effect. In studies done in Western countries (David et al., 1998; Weisbach, 1988), it was proven that the existence of institutional investors and independent directors made sure that executives' compensation is more closely related with corporate performance. In the Chinese market, we did not find a similar result.

According to Xie (2004), when the board of directors actually owns the claim on the residual of the enterprise, an independent director, in essence, is a manager and one part of the agent problem. In China, relevant departments did not realize this issue, which is the key reason for the absence of a significant relationship between independence of independent directors and corporate performance. Since we tested whether executives' equitybased compensation is positively related to corporate performance, it is apparent that in the current China stock market, the independent directors do not affect executive's compensation level. To some extent, they may have the same interests as managers do.

Chinese researchers also did several studies on institutional investors' developments. Li and Caiping (2007) found that in the Chinese stock market, not all shares could be traded freely. Under "one share has one decision- 
making right" system, institutional investors, which are referred to as fund companies in particular, can hardly have claim to express their opinions on important issues of corporate development for owning less shares under such a circumstance.

It is difficult to accurately valuate human capital, which is so comprehensive and intangible. Using only one variable may not be sufficient. That's why Western researchers (Hartzell, 1998; Hill and Phan 1991; Murphy, 1986) have failed to reach such consensus, even for the factor of tenure. Therefore, a model for valuing human capital needs to be employed in subsequent research.

Industry is an experimental variable that yielded positive but unsurprising results. Every industry is at a different stage in its life cycle. Some are in the sunrise period, while others are in the sunset period. This gives rise to significant differences among industries in terms of probability, administrative habits and incentive momentum. We believe the industry factor will continue to play an influential role in the long run as long as the process of averaging the profitability exists, and many new industries will emerge with the rapid development of science and technology.

In addition, the issue of executive compensation is not simply an agency theory problem, a managerial power problem, or a human capital problem, but also a problem influenced by multiple factors. These factors include nationality, region, politics, society, culture, outside environment of the corporation, corporate performance, corporate nature (ownership), corporate industry, corporate governance, executives' characters, etc. Therefore, there exists much scope for further study in this field.

\section{Implications}

From a global point of view based on the above discussion, we would like to suggest that companies, especially multinational corporations, further investigate whether their executives' equity-based compensation plan could be improved by giving more consideration to the national, institutional and cultural factors to improve the compensation system.

China is undergoing economic transformations. All capital resources are in the process of reevaluation, as is human capital. There is a trend that Chinese human capital will be further recognized and more accurately valuated. Professional managers today receive more recognition by the market than 10 years ago. Generally speaking, the total environmental factors in China are changing and China will gradually become more market-oriented as GDP grows.

However, the current context in which executive reward is embedded in China still lies in the shadow of a planned economy. As the State is also the owner of large SOEs, it has the power to appoint and reward managers through the State-Owned Assets Supervision and Administration Commission.

Learning from foreign large companies with advanced management systems, Chinese companies, especially experimental pioneers, which are listed on stock exchanges, are trying to establish the so called modern enterprise system. Several new approaches have been tested. Some of the experiments have resulted in failures because of the inappropriate adaptation, while others, like equity-based long-term incentive, are helping to achieve high-level business results.

\section{CONCLUSION}

Based on the above analysis, we suggest future improvements of the current situation in order to establish a healthier equity incentive system that will be more appropriate to the Chinese current condition.

First, establish a more normative human resource market, especially for senior management, so as to capitalize their value. Executives are generally nominated or appointed by superiors rather than openly recruited from the human resource market. Furthermore, their compensation is not decided according to the market level. As China deepens its economic reforms, all relevant capital allocated to the market needs to be established and improved. The human capital market inevitably becomes the key area of development in the next step. 
Second, keep enhancing the operation as well as governance quality of listed companies. In our study, we witnessed some impressive progress of the managerial competence in Chinese-listed companies. However, in Chinese companies, there are still some unresolved management issues that will hamper further development, such as issues of insider control and outsider internalization. This raises the problem of insider control which mainly refers to the phenomena that management or labor, that has grasped the residual claim of non human resource capital, will naturally seek their individual interests. In China, the situation is more complex. It is the representatives from State-owned Assets Supervision and Administration Commission who occupy the position of the capital owner. The current practice of one representative having the responsibility of supervising several SOEs causes the actual problem of investor vacancy. It gives executives who work in listed companies owned by the state much freedom to seek their own benefits. Therefore, it is very important to modify the current supervision system to give actual owners more power in determining the compensation of the managers they employ.

Third, perfect the rules and regulations of equity incentive systems. In the year 2006, most listed companies in the Shanghai and Shenzhen security exchange markets executed the share merger reform. Along with this reform, the equity incentive plan was also spread out as a way to receive these shares. As it is the big official beginning of such an incentive trend, rules and regulations need to be produced ahead of execution.

Finally, continue to cultivate the capital market and more mature institutional investors in the Chinese exchange market. The Chinese economy is subject to a period of high speed GDP growth but with a low-efficiency financial market. Without an efficient capital market, corporate value will not be discovered and rationally reflected. Cultivating the capital market means developing a healthier administration system, introducing a value investment environment, and improving the relevant law system. It is also important to develop mature Chinese institutional investors. Large fund companies and insurance companies are to be developed as a priority objective and the key developmental direction is to let these institutional investors not only take the responsibility of managing the agent fund, but also to be involved in the supervision and administration of the shareholding companies.

\section{AUTHOR INFORMATION}

Lei LI holds a doctorate degree in business administration from Grenoble Ecole de Management (France). He has been working with multinational companies for over 15 years in various managerial capacities. He is a frequent guest speaker for western MBA and EMBA students on their international study trips to China, witnessing the exciting dynamics of China economic growth. Lei LI is currently the Vice President, Human Resources for APAC area with an international corporation, commuting between China and Singapore.

Pierre-Yves Sanséau is Professor at Grenoble Ecole de Management (France). He holds a Ph.D. and a HDR in business administration from the University of Lyon (France), a MBA (Montreal, Canada) and a M.Sc. in Political Sciences. His research interests include intercultural management, management of technology, management of competences, working time, work-life integration and life-long learning. Dr SANSÉAU is Visiting Scholar at San

Jose State University Graduate School of Business (California) and member of the Chair Management of competences at the University of Quebec in Montreal, Canada. E-mail: pierre-yves.sanseau@grenoble-em.com (Corresponding author)

\section{REFERENCES}

1. Benz, M., Kucher, M. and A. Stutzer. (2001). Stock Options: The Managers Blessing: Institutional Restrictions and Executive Compensation. University of Zurich, Institute for Empirical Research in Economics Working Paper. No. 61.

2. Bertrand, M. and Mullainathan, S. (2001). Are CEOs rewarded for luck? The ones without principles are, Quarterly Journal of Economics, 116: 901-932.

3. Cadenillas, A., Jaksa C. and Zapatero F. (2004). Leverage decision and manager compensation with choices of effort and volatility. Journal of Financial Economics, 73, 71-92.

4. Carpenter, J. (2000). Does option compensation increase managerial risk appetite? Journal of Finance, 55, 2311-2331. 
5. Chidambaran, N.K. and Nagpurnanand P. (2003) .Executive stock option repricing, internal governance mechanisms, and management turnover. Journal of Financial Economics, 69, 153-189.

6. Ciscel, D. H. and T. M. Carroll. (1980). The determinants of executive salaries: an econometric survey. The Review of Economics and Statistics, 62 (1): 7-13.

7. Conyon M., Leech, D. (1994). Top pay, company performance and corporate governance. Oxford Bulletin of Economics and Statistics, 56: 229-247.

8. Core, J. and Guay, W. (1999). The use of equity grants to manage optimal equity incentive levels. Journal of Accounting and Economics, 28(2):151-184.

9. Core, H., and D. F. Larcker. (1999). Corporate Governance, Chief Executive Officer Compensation and Firm Performance. Journal of Financial Economics, 51: 371-406.

10. Cragg, M. I., and I. J. Dyck. (2000). Executive Pay and U.K. Privatization: The Demise of One Country, Two Systems. Journal of Business Research, 47: 3-18.

11. Cyert, R. M., Kang, S. H., and Kumar, P. (2002). Corporate governance, takeovers, and top-management compensation: Theory and evidence, Management Science, 48: 453-469.

12. David, P., Kochar, R., and Levitas, E. (1998). The effect of institutional investors on the level and mix of CEO compensation. Academy of Management Journal, 41: 200-208.

13. Demsetz, H. and Lehn, K. (1985). The structure of corporate ownership: cause and consequences. Journal of Political Economy, 93(6): 1155-77.

14. Garen, J. E. (1994). Executive compensation and principal agent theory. Journal of Political Economy, 102 (6): 1175-1199.

15. Gomez-Mejia, L.R. (1994). Executive compensation: A reassessment and future agenda. Research in Personnel and Human Resources Management, 12:161-222.

16. Griner, E. H. (1995-1996). Corporate performance, Stock Option compensation and measurement error in CEO Pay, Journal of Applied Business Research, 12(1).

17. Gregg, P., Machin, S., and Szymanski, S. (1993). The disappearing relationship between directors' pay and corporate performance. British Journal of Industrial Relations, 31: 1-9.

18. Hall, B. and Liebman, J.B. (1998). Are CEOs really paid like Bureaucrats? Quarterly Journal of Economics, 113(3): 653-691.

19. Hartzell, J.C. (1998). The Impact of the Likelihood of Turnover on Executive Compensation. NYU Working Paper. No. FIN-98-090.

20. Hill, Ch. W. L. and Phan, P. (1991). CEO tenure as a determinant of CEO's pay. Academy of Management Journal, 34 (3): 712-717.

21. Himmelberg, Ch. P., Hubbard, R. G and Palia, D. (1999). Understanding the determinants of managerial ownership and the link between ownership and performance. Journal of Financial Economics, 53:353-384.

22. Jensen, M; and Meckling, W. (1976). Theory of the firm: managerial behavior, agency cost, and ownership structure. Journal of Financial Economic, pp. 305-360.

23. Jensen, M.C. and Murphy, K.J. (1990). Performance and top management incentives. Journal of Political Economy, 98(2), 225-264.

24. Johnson, S. and Tian, Y. (2000). The value and incentive effects of non-traditional executive stock option plans. Journal of Financial Economics, 57, 3-34.

25. Laffont, J.-J. and Martimort, D. (2002). The Theory of Incentives: The Principal-Agent Model, Princeton University Press.

26. Li S. and Wang C. (2007). Empirical research on the relation between institutional shareholding and compensation for top management in Chinese-listed companies. Management Review, 19(1):41-48.

27. Liu, Y.; Li, Y. and J. Xue. (2011). Ownership, strategic orientation and internationalization in emerging markets. Journal of World Business: 381-393.

28. McKnight Ph-J, Tomkins, C. and Ch. Weir. (1996). CEO Age and Top Executive Pay: A UK Empirical Study. Journal of Management and Governance. 4:173-187.

29. McConvill, J. (2005). Positive corporate governance \& executive compensation, German Law Journal, 6(12):1777-1804.

30. Murphy, K-J. (1986). Incentives, learning and compensation: a theoretical and empirical investigation of managerial labor contracts. Review and Journal of Economics, 17(1):59-76.

31. Peng B. (2006). Empirical Research on the relation between top management compensation level and corporate governance in Chinese-listed companies. Shandong Social Sciences, 125(1):118-122. 
32. Peterson, R.M, Dibrell, C.C. and T.L. Pett. (2002). Long- vs. short-term performance perspectives of Western European, Japanese, and U.S. countries: where do they lie? Journal of World Business, Volume 37(4): 245-255.

33. Ross, S. (2004). Compensation, incentives, and the duality of risk aversion and riskiness. Journal of Finance, 59, 207-225.

34. Sircar, R. and Xiong, W. (2007). A General Framework for Evaluating Executive Stock Options. Journal of Economic Dynamics and Control, Volume 31-7, 2317-2349.

35. Smith C. and Watts L. R. (1992). The investment opportunity set and corporate financing dividends, and compensation policies. Journal of Financial Economics, 32(3):263-292.

36. Wei G. (2000). Senior Management Incentive and Operation Performance of Listed Companies. Economic Research, (3):32-39.

37. Weisbach, M.S. (1988). Outside directors and CEO turnover. Journal of Financial Economics, 20:431-460.

38. Xie D. (2004). Executive Incentive and Stock Option, China Renmin University Press.

39. Yang H. and Ma C. (2005). Impacts of Executive Control on Senior Manager's Compensation: Empirical Study of Listed Companies Offering Annual Salary Scheme. Journal of Management Sciences, 18(3): 2428.

40. Yu X. and Peng Z. (2001). Little River and Small River, the impact of the payment to executives on companies. Modern Industry and Commerce, 3: 68-70.

41. Zhang R. (2003). An Empirical Study on the Correlation Between Operators' Incentive Compensation and Firm's Performance in Listed Firms. Accounting Research, (9):29-34.

42. Zhang Z. and Tao X. (2002). Actuality and Prospect of Overseas Theory of Manager's Emolument. Coal Economic Research. (1):22-25.

43. Zhou J. and Sun J. (2003). Review on Stock Options for Senior Management of Chinese Public Companies, Securities Market Herald.

44. Zhou L. (2003). Determinants of Senior Executives' Compensation in Chinese-listed Company. Quantitative \& Technical Economics, (10):123-127. 